\title{
Spacing and parental behavior in the Mongolian vole (Microtus mongolicus)
}

\section{Polina S. Dontsova, Antonina V. Smorkatcheva* \& Yury A. Bazhenov}

\begin{abstract}
The relationship between parental care patterns and mating system in voles has not been fully elucidated. Whereas mating and parental strategies have been reported for many New World arvicolines, such information is lacking for most Palearctic voles. Nothing is known about the social organization of Microtus mongolicus inhabiting mesic habitats of Central Asia. We investigated spacing of free-ranging $M$. mongolicus in Zabaykalsky Kray using mark-recapture method, and we assessed the parental care exhibited by Mongolian voles in laboratory. Home ranges (HR) and movement distances of overwintered males exceeded those of other categories of voles. HR overlapped within sexes and between sexes in linear habitat at high population density as well as in non-linear habitat at low density. The revealed pattern of spacing is consistent with promiscuous mating system. In laboratory, both the parent-litter separation tests and undisturbed observations of animals in large enclosures showed that most males displayed paternal behavior at the level comparable to that of socially monogamous species. Our results demonstrate that monogamous mating system cannot be inferred from biparental care detected in captivity.
\end{abstract}

KEY WORDS: Microtus mongolicus, Arvicolinae, voles, spatial organization, mating system, paternal behaviour.

Polina S. Dontsova, Department of Vertebrate Zoology, Saint Petersburg State University, Universitetskaya nab. 7/ 9, Saint Petersburg 199034, Russia; Antonina V. Smorkatcheva [tonyas1965@mail.ru], Department of Vertebrate Zoology, Saint Petersburg State University, Universitetskaya nab. 7/9, Saint Petersburg 199034, Russia; Yury A. Bazhenov, State Nature Biosphere Reserve "Daursky”, Nizhny Tsasuchey 674480, Zabaykalsky Kray, Russia; Institute of Natural Resources, Ecology and Cryology, Siberian Branch of the Russian Academy of Sciences, Chita 672014, Russia.

\section{Пространственные отношения и родительское поведение у монгольской полёвки (Microtus mongolicus)}

\author{
П.С. Донцова, А.В. Сморкачева, Ю.А. Баженов
}

РЕЗЮМЕ. Связь между характером родительской заботы и брачной системой у полёвок не вполне ясна. В то время как для многих видов полёвок Нового Света были описаны стратегии спаривания и родительского поведения, для большинства палеарктических видов такая информация отсутствует. О социальной организации монгольской полёвки (Microtus mongolicus), распространенной в Центральной Азии, в настоящее время ничего не известно. Мы исследовали пространственную структуру популяции M. mongolicus в Забайкальском крае, используя метод повторных отловов меченых особей, а также сравнили уровень родительского поведения самок и самцов в лабораторных условиях. Участки обитания (УО) и суточные дистанции перемещения были больше у взрослых самцов, чем у особей других поло-возрастных категорий. Как в линейном местообитании при высокой плотности популяции, так и в нелинейном местообитании при низкой численности УО особей одного пола и разных полов перекрывались. Такой характер взаимного расположения УО согласуется с предположением о промискуитете. В лабораторных тестах и наблюдениях большинство самцов демонстрировало уровень отцовского поведения, сравнимый с таковым социально моногамных видов. Наши результаты показывают, что проявление отцовской заботы в условиях неволи не является свидетельством социальной моногамии.

КЛЮЧЕВЫЕ СЛОВА: Microtus mongolicus, Arvicolinae, полёвки, пространственная организация, система спаривания, отцовское поведение.

* Corresponding author 


\section{Introduction}

Despite a progress in investigations of the genetic, neural and endocrine mechanisms underlying social and reproductive behavior, our understanding of the evolution of behavioral patterns is elusive. During the last few decades, extensive species sampling, coupled with advances in field and laboratory techniques, revealed numerous examples which are in poor agreement with a traditional idea about strict evolutionary association between monogamy and paternal care in mammals (Storey \& Snow, 1987; Gajda \& Brooks, 1993; Komers \& Brotherton, 1997; Buchan et al., 2003; Fietz \& Dausmann, 2003; Schradin \& Pillay, 2003).

The subfamily Arvicolinae Gray, 1821 (here and hereafter we use taxonomy after Wilson \& Reeder, 2005), includes more than 150 species which show different patterns of ecological specialization, life-history, spatial and social structures. Spectrum of vole mating systems includes polygyny with territorial males overlapping several clumped females, promiscuity in which non-territorial males compete for access to territorial females, monogamy and even cooperative polyandry based on pair-bonding and group territoriality (Ostfeld, 1985; Ims, 1987; Gaulin \& FitzGerald, 1988; Tab. 1). Although paternal care in voles is thought to vary as a function of mating system (Dewsbury, 1985; Oliveras \& Nowak, 1986; Tab. 1), the actual nature of the relationship between these two variables in arvicolines has not been fully elucidated. For two monogamous species, Microtus ochrogaster (Wagner, 1842) and Microtus pinetorum (Le Conte, 1830), the results obtained in captive studies of parental behavior were always completely consistent with their social and mating systems (joined nesting, pronounced paternal care). In contrast, several promiscuous species expected to be uniparental display both interspecies and intraspecies variations in the level of paternal behavior (see for review McGuire \& Bemis, 2007; Gromov, 2013).

The modern comparative method provides a valuable tool to test the evolutionary correlations between characters. An impressive insight into Microtus Schrank, 1798, phylogeny (Conroy \& Cook, 2000; Jaarola et al., 2004; Galewski et al., 2006; Abramson et al., 2009; Bannikova et al., 2010) generated the opportunity of using this genus as a study system for phylogenetically informed comparative researches. Unfortunately, such opportunity is limited by extremely uneven availability of data about social biology across several evolutionary lineages of this genus. While the detailed information has been reported for many New World species, mating and parental strategies of most members of Palearctic clades are little known.

The Mongolian vole, Microtus mongolicus (Radde, 1861), was first considered to be a well differentiated subspecies within Microtus arvalis sensu lato, but cytogenetic and molecular studies confirmed its full species status and revealed its affiliation to the subgenus or genus Alexandromys (Meyer et al., 1996; Bannikova et al., 2010). This species is widely distributed throughout the mesic habitats of Central Asia. Literature data on the M. mongolicus behavior are virtually anecdotal (Nekipelov, 1935; Zorenko, 1986; Bazhenov, 2011).

The first goal of this study was to characterize the pattern of ranging by wild Mongolian voles. Specifically, we aimed to reveal whether spacing of M. mongolicus is consistent with one typical for monogamous, polygynous or promiscuous species (Tab. 1). Our second goal was to estimate the level of paternal behavior under laboratory and semi-natural conditions. Using the data obtained, we test whether there is a consistency between the parental strategy and mating system inferred from spatial data (Tab. 1).

\section{Materials and methods}

\section{Field study of spacing}

Study area and field procedures. The study was performed 15 June - 5 July 2011 and 16 June - 8 July 2013. The study area was located in Zabaykalsky Kray, Russia, near the small freshwater lake Butyvken in the

Table 1. Behavioral characteristics predicted for arvicoline species with different mating systems (Dewsbury, 1985; Ostfeld, 1985; Oliveras \& Nowak, 1986; Ims, 1987; Gaulin \& FitzGerald, 1988).

\begin{tabular}{|c|c|c|c|c|c|c|}
\hline \multirow{2}{*}{$\begin{array}{c}\text { Behavioral } \\
\text { characteristics }\end{array}$} & \multirow{2}{*}{ Space size } & \multicolumn{2}{|c|}{ Intrasexual overlap } & \multicolumn{2}{|c|}{ Intersexual overlap } & \multirow{2}{*}{ Paternal care } \\
\hline & & $\begin{array}{c}\text { male } \\
\text { spacing }\end{array}$ & $\begin{array}{l}\text { female } \\
\text { spacing }\end{array}$ & $\begin{array}{l}\text { males overlap with } \\
>1 \text { females }\end{array}$ & $\begin{array}{c}\text { females overlap } \\
\text { with }>1 \text { males }\end{array}$ & \\
\hline Promiscuity & $\mathrm{M}>\mathrm{F}$ & yes & no & yes & yes & no \\
\hline Polygyny & $\begin{array}{c}M>F \text { or } \\
M=F\end{array}$ & no & yes or no & yes & no & sometimes \\
\hline Monogamy & $\mathrm{M}=\mathrm{F}$ & no & no & no & no & extensive, \\
\hline $\begin{array}{c}\text { Cooperative } \\
\text { polyandry }\end{array}$ & $\mathrm{M}=\mathrm{F}$ & yes & no & no & yes & $\begin{array}{c}\text { comparable with } \\
\text { maternal }\end{array}$ \\
\hline
\end{tabular}


middle of a pine forest (N 50²6'16.6", E 11455'04.9”). Mongolian voles inhabited shoreline with willow (Salix sp.) and birch (Betula sp.) shrubs and high grass cover dominated by hummocky reed grass (Calamagrostis sp.), common reed (Phragmites sp.) and fireweed (Chamerion sp.). Other rodent species encountered in the study area were Microtus (Stenocranius) gregalis (Pallas, 1779), Microtus (Alexandromys) fortis Büchner, 1889, and Cricetulus barabensis (Pallas, 1773). The preliminary trapping carried out during the first decade of June 2011 revealed the absolute prevalence of $M$. mongolicus over other rodent species within the narrow band of preferred habitat restricted from north and south by open areas strongly avoided by Mongolian voles. Eastern end of the trap line adjoined the shoreline section mainly inhabited by $M$. gregalis. The width of the suitable habitat varied from 5 to $15 \mathrm{~m}$. The data on the home range lengths reported for several Microtus species (Miller \& Getz, 1969; Abramsky \& Tracy, 1980; Gaines \& Johnson, 1982; FitzGerald \& Madison, 1983) suggest that the configuration of this biotope only allowed the vole home ranges to lie in a line. Thus, we considered this habitat as linear. A $300 \mathrm{~m}$ trap line was laid out with 60 Sherman live traps $(5 \times 6 \times 16 \mathrm{~cm})$ placed of $5 \mathrm{~m}$ apart. During the last three days of the study we extended the trap line by $80 \mathrm{~m}$ to the west in order to estimate the home range sizes for the animals which had been trapped at the west end of the $300 \mathrm{~m}$ line.

There was a crash of rodents in 2013. Mongolian voles were absent from the most of the lake shoreline including the former study site. They were only found at a limited area of about 0.3 ha on the opposite bank of the lake. Trapping was performed on a $7 \times 7 \mathrm{~m}$ grid entirely covering this area.

All traps were baited with mixture of sunflower seeds and oats, and set between 6 and 7 PM. They were checked on the same night at 10-11 PM, the next morning at 6-7 AM and 9-10 AM, and then left unset until the evening because of the danger of death of animals from overheating. Each vole was marked by toe-clipping upon initial capture. At each capture the number, trap location, sex, weight, and reproductive condition (males: scrotal or nonscrotal; females: pregnant, lactating, open or closed vaginal opening) were noted. All animals were released immediately at the place of capture.

Demographic background. Population density of the Mongolian voles was high (about 150 voles/ha in the areas with preferred vegetation) in 2011 but very low (less than 20-30 voles/ha in the areas of local concentration) in 2013. We captured a total of 66 voles in 2011 and 19 voles in 2013. The dynamics of the age structure of population was similar in both years. Based on the weight and pelage characteristics, two categories of voles could be clearly identified in June: (i) fullygrown adult, apparently overwintered animals (body mass $>27 \mathrm{~g}$ in females and $>32 \mathrm{~g}$ in males at the beginning of the study) and (ii) young of the year of the first cohort apparently born in early May (body mass $<25 \mathrm{~g}$, in most cases $12-19 \mathrm{~g}$ by the middle of June). Juveniles of the second cohort born in early June appeared in the end of June - beginning of July. Through both 2011 and 2013 study periods, all overwintered females and all young females of the first cohort were reproductive, i.e. displayed vaginal perforation, signs of pregnancy and/or lactation. Based on dynamics of body masses and nipple conditions we were able to determine the exact or approximate ( \pm 2 days) date of deliveries for seven overwintered females and five females of the year in 2011 and for two females of the year in 2013 .

Among males, all overwinters were mature (scrotal) while most of young of the year had abdominal testes through the study periods.

Data analysis. For the purpose of this study we analyzed the data on ranging and movements for four age-sex vole categories: overwintered male and female, male and female voles of the first cohort of the year. We classified each vole as resident or non-resident. An animal was classified as "resident" based on two criteria: (i) the minimum number of captures of 6 , and (ii) the minimum duration of residence (= interval between the first and the last captures) of 10 days (McGuire \& Getz, 1998).

We used several parameters to estimate the differences in space use between age-sex categories. Because of limited sample sizes in 2013, only the data obtained in 2011 were statistically analyzed. First, we calculated proportions of resident individuals for each age-sex category. We used a Fisher's exact test of independence to test whether in 2011 the proportion of residents depended on age-sex category. Second, we assessed home range sizes for the resident voles of each age-sex category. Because of the difference in habitat configuration, different indexes of home range size were used for the data obtained in 2011 and 2013. In 2011, we found home range length (hereinafter - HRL) for each resident as maximum distance in meters between capture points (Gaines \& Johnson, 1982; Pusenius \& Viitala, 1995). The number of captures for each HRL value varied from 6 to 35 (mean 17.5). To estimate the effect of age-sex category on HRL, the oneway ANCOVA with a number of captures as a covariate was used. Post-hoc comparisons were performed using unequal N HSD test. In 2013, trapping was performed in a non-linear habitat. Home ranges were plotted according to the Minimum Convex Polygon (MCP) method using recapture data. Third, we calculated daily movement distances (hereinafter - DMD) as the distances between trap locations visited no more than 24 hours apart. We used a Mann-Whitney test to estimate the significance of pairwise differences between agesex categories in average and maximum DMD in 2011. Only the data for the individuals with three or more DMD values were included into this analysis. For each resident vole, the number of male and female residents and non-residents captured within its home range dur- 
ing its residence period was found. We report these data as median and limits for each age-sex category, and plot home ranges of resident voles for visualization. In addition, we calculated the number of overwintered (=reproductive) males known to overlap female home range during the period encompassing the presumed day of delivery (followed by postpartum estrus in all Microtus species, see Hasler, 1975) \pm 1 day.

\section{Laboratory study of parental behavior}

Animals and housing. Voles used in these experiments were first and second generation laboratory-reared outbred animals derived from voles caught in Zabaykalsky Kray in 2011. Breeding pairs were housed in glass aquaria $(25 \times 60 \times 30 \mathrm{~cm})$ half-filled with wood shavings and provided with a wooden box for nesting. Toilet paper served as nesting material. Carrot, apples and oats were provided ad lib. In addition, small amounts of fresh grass and sunflower seeds were provided. The voles were maintained on a 16/8-h light/ dark cycle (lights on at $7 \mathrm{AM}$ ) at an ambient temperature of $19-23^{\circ} \mathrm{C}$.

Assessment of parental responsiveness in standard tests. We used the widely applied parent-litter separation paradigm (Storey \& Joice, 1995; Lonstein \& De Vries, 1999; Parker \& Lee, 2001; de Jong et al., 2009) to estimate and compare the parental responsiveness of M. mongolicus sires and dams in the absence of their mates. We formed 15 breeding pairs using unrelated males and females at the age of 90-180 days which had no parental experience. Animals were then left undisturbed except to inspect females weekly until late pregnancy. After that time, we inspected the nest every other day for birth of pups. Males were not removed from the nest after pup's appearance. We determined the pup's exact age by the external signs (skin pigmentation and auricle condition). Paternal responsiveness was assessed through standard behavioral tests on day 3-5 after birth of the first litter (day $0=$ day of birth). A mother and a father were tested 1 hour apart with different pups. Order of testing had no effect on parental responsiveness. All tests were conducted between 9 AM and 1 PM. Testing procedure is described in details elsewhere (Smorkatcheva et al., 2010). Briefly, an adult vole was moved from the home cage into a clean cage for 30 minutes, after which time the subject was placed into the testing aquarium. The testing aquarium was of similar dimensions to the subject's home cage $(25 \times$ $60 \times 30 \mathrm{~cm})$. A clean wooden semi-open box $(10 \times 15 \times$ $7 \mathrm{~cm}$ ) was put into a corner of the aquarium to provide a shelter. After a 15-min habituation period, one pup from the subject's litter was put in the farthest corner of the aquarium from where the male was sitting (usually the corner with the box), and the parental behaviors directed towards pups were continuously recorded for the next $20 \mathrm{~min}$.

Licking and being in tactile contact with pup (while performing any activities or not) were collected by scan sampling (Altmann, 1974) at 5-s intervals, providing
240 data points per testing period. For pup retrieval, the number of occurrences per 20-min period was recorded (all occurrence sampling, Altmann, 1974). We also recorded latency (number of scans) in approaching the pup. Subjects that did not approach the pup during the 20 -min test were arbitrarily assigned a latency of 240 scans. All animals were returned back to the home cage in the end of the test.

The percentages of mothers and fathers acting parentally (i.e. making any contact with a pup) and the percentages of mothers and fathers licking pups were compared with a Fisher's Exact Probability test. The significance of sex differences in latency in approaching the pup, the number of pup retrievals and duration of the remaining pup-oriented behaviors was estimated with nonparametric Wilcoxon matched-pairs test.

Assessment of parental behavior in semi-natural setting. In captive rodents housed in small cages, paternal behavior may be an artifact resulting from space limitation and forced living of males together with nursing females and pups (Hartung \& Dewsbury, 1979; Xia \& Millar, 1988; Schradin \& Pillay, 2005). Thus, we quantified the care-giving behavior of animals housing in large pen where members of a pair had opportunity to share nests or to use separate shelters. The observation pen was a square enclosure of $9 \mathrm{~m}^{2}$ with a tile floor and 70 -cm-high sides of aluminum sheets. Each pen contained two metal cylindrical nest boxes (height $=50 \mathrm{~cm}$, diameter $=30 \mathrm{~cm})$ with one side entry. The cameras with infrared backlight were installed into the box roofs. This arrangement allowed us to observe behavior with minimal interference. Temperature, photoperiod and diet remained unchanged, but the voles in the pens had access to water.

Food as well as water was provided in dishes ad lib. The floor of the pen was powdered by sand mixed with small amounts of wood shavings. Multiple narrow strips of dark polyethylene were stretched above the pen in order to make uneven shading imitating to some extent shading from vegetation in natural environment. No nest material was provided in pens as elaborated nests would obscure videotaping of parental-pups interactions.

By the time when this experiment was carried out, the number of breeding pairs was limited. We used 4 pairs which had previously reared a litter without being observed. Members of a pair were moved into the pen after the female had showed a drastic gain in weight and embryos could be detected by abdominal palpation. One member of a pair was marked by fur cutting to easily distinguish male from the female.

Videotaping were performed on 1-2 and 5-6 days after delivery (day $0=$ day of birth) on the following schedule: 2:00-2:40 AM, 5:00-5:40 AM, 8:00-8:40 AM, 11:00-11:40 AM, 2:00-2:40 PM, 5:00-5:40 PM, 8:00-8:40 PM, 11:00-11:40 PM, providing 32 observation sessions for each pair.

The following parameters were analyzed for both the mother and the father: time spent in the brood nest; 


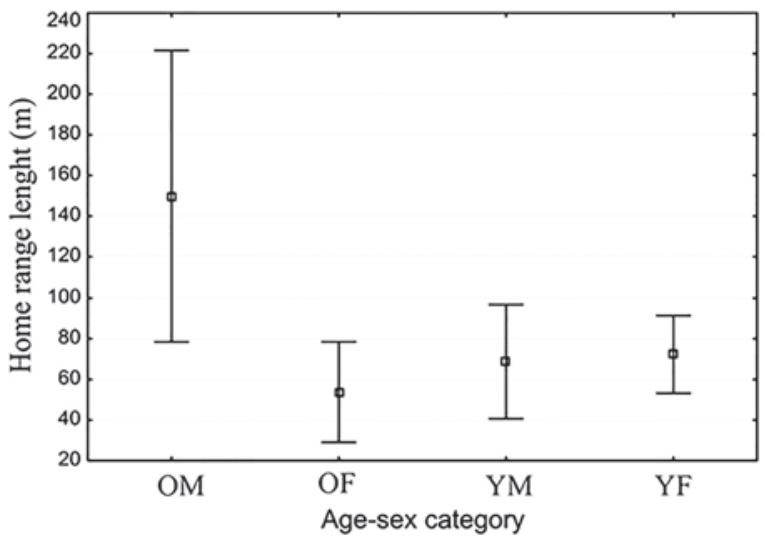

Fig. 1. The mean $( \pm \mathrm{SD})$ home range length measured as the largest distance between capture points of a given resident Mongolian vole in 2011. OM - overwintered males $(n=4)$; $\mathrm{YM}$ - males of the year $(n=8)$; OF - overwintered females $(n=8)$; YF - females of the year $(n=13)$.

time spent in tactile contact with at least one pup; time spent on licking pups; retrieving pups. Duration of each behavior except retrieval was measured in seconds per a 40-minute session. For pup retrieval, the number of occurrences was recorded. Within each pair, we compared the behavior of two parents using 32 observation sessions as data points. Sex differences in nest-residence, tactile contact and grooming were estimated with Wilcoxon matched-pairs tests. We used the Chisquare test of goodness-of-fit to compare the total number of instances of retrieving by male and female voles. Statistical significance in all cases was $p<0.05$.

\section{Results}

Spacing in free-living Mongolian voles

Proportion of residents. In 2011, four of 10 overwintered males $(40 \%)$, eight of 19 males of the year

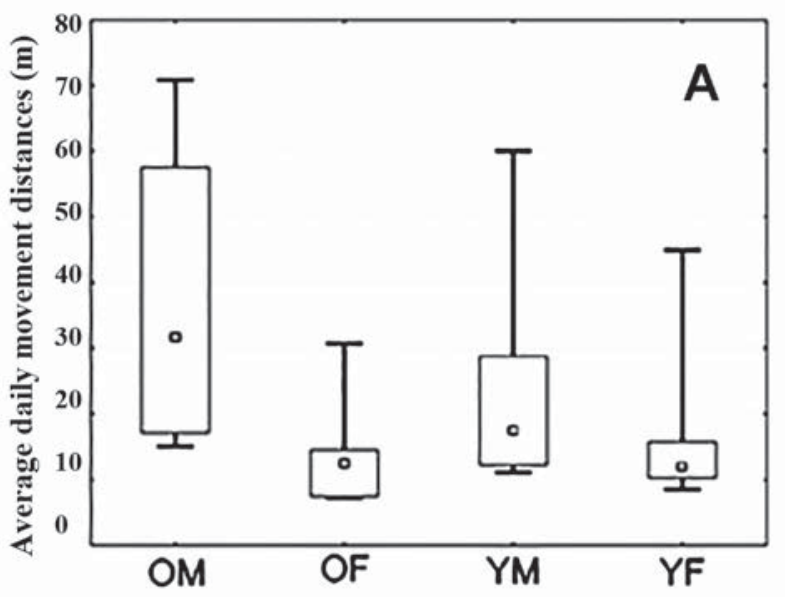

Age-sex categories
(42\%), eight of 11 overwintered females (72\%) and 13 of 18 females of the year $(72 \%)$ were classified as residents. There was significant association between age-sex category and the proportion of residents $\left(\chi^{2}=\right.$ 8.65; $\mathrm{df}=3 ; p=0.034)$. The pairwise comparisons did not reveal significant difference between sexes within any age group or between ages within each sex. However, when two age categories within each sex were pooled, the difference between males and females was significant $\left(\chi^{2}=5.69 ; \mathrm{df}=1 ; p=0.017\right)$.

In 2013, three of five overwintered males, none of four males of the year, two of three overwintered females and the same number of females of the year were classified as residents.

Home ranges sizes and daily movement distances. In 2011, the number of recaptures did not influence HRL of resident voles $\left(\mathrm{F}_{1,28}=0.857 ; p=0.362\right)$, while the effect of age-sex category was highly significant $\left(\mathrm{F}_{3,28}=7.60 ; p=0.001\right)$. HRL of overwintered males were longer than those of overwintered females ( $p=$ $0.001)$, females of the year $(p=0.009)$ and males of the year $(p=0.006)$ (Fig. 1). Adult males had significantly higher average and maximum DMD than overwintered females (average: $Z=2.31 ; p=0.021$; maximum: $Z=$ $2.09 ; p=0.037$ ) and females of the year (average: $Z=$ 2.04; $p=0.041$; maximum: $Z=2.23 ; p=0.026)$. All other differences were insignificant (Fig. 2).

In 2013 the estimated home range sizes for three overwintered males ranged from $773.2 \mathrm{~m}^{2}$ ( $n$ of captures $=24$ ) to $1402.9 \mathrm{~m}^{2}$ ( $n$ of captures $=15$ ). Two overwintered females had home range size of $125.3 \mathrm{~m}^{2}$ $(n$ of captures $=9)$ and $199.9 \mathrm{~m}^{2}(n$ of captures $=15)$ while these values in two females of the year were $250.0 \mathrm{~m}^{2}(n$ of captures $=8)$ and $852.8 \mathrm{~m}^{2}(n$ of captures $=$ 22). The average DMD determined for three adult resident males ranged from $13.9 \mathrm{~m}$ to $35.0 \mathrm{~m}$, and the maximum DMD - from 30.0 to $67.1 \mathrm{~m}$. Two resident overwintered females had average DMD of $10.7 \mathrm{~m}$ and $23.3 \mathrm{~m}$, and the maximum DMD -15.8 and $41.2 \mathrm{~m}$.

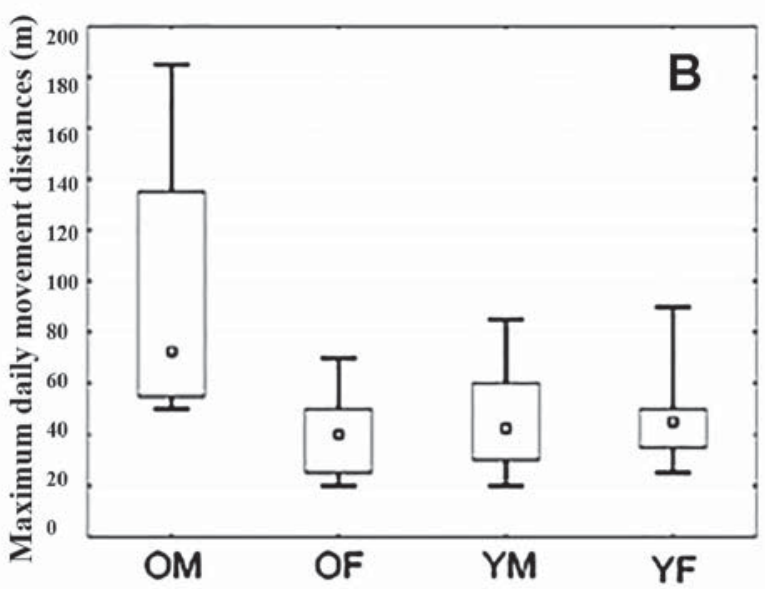

Age-sex categories

Fig. 2. The daily average (A) and maximum (B) movement distances of the Mongolian voles in 2011. Medians and first and third quartiles are presented. Abbreviations for age-sex categories as in Fig. 1 (OM: $n=4$; YM: $n=9$; OF: $n=6$; YF: $n=13$ ). 


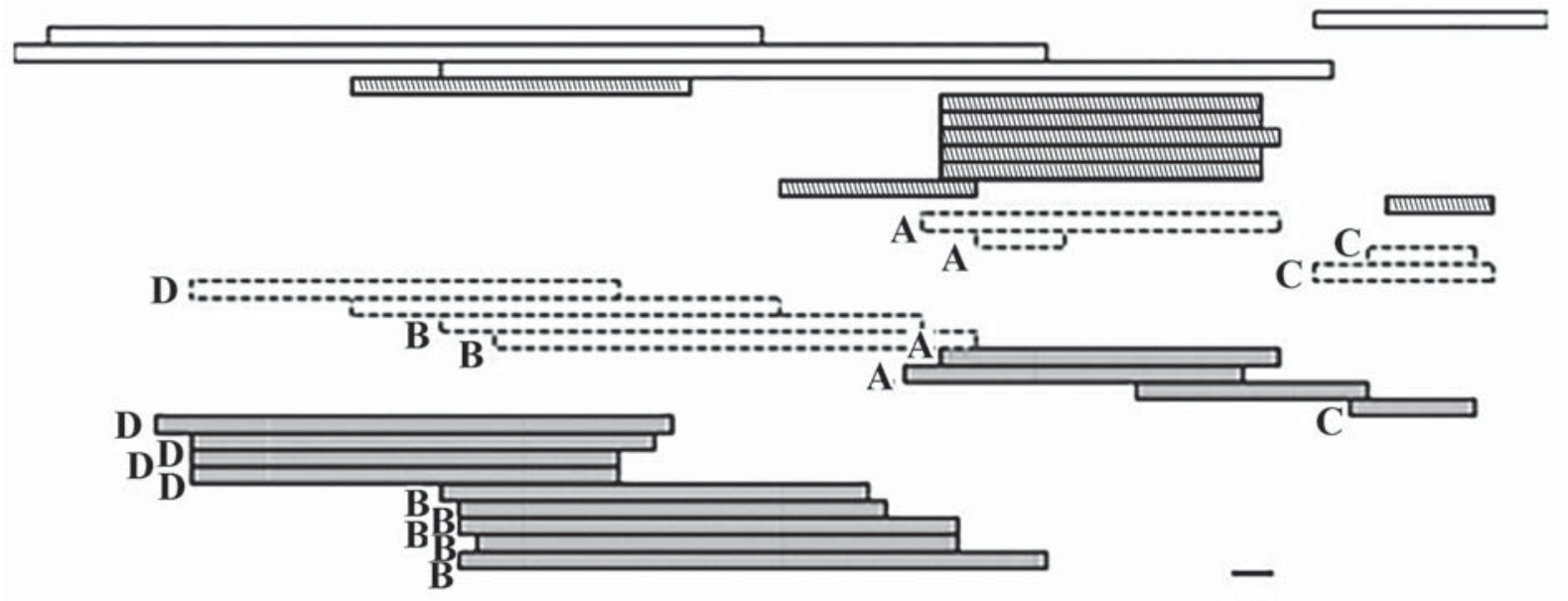

A

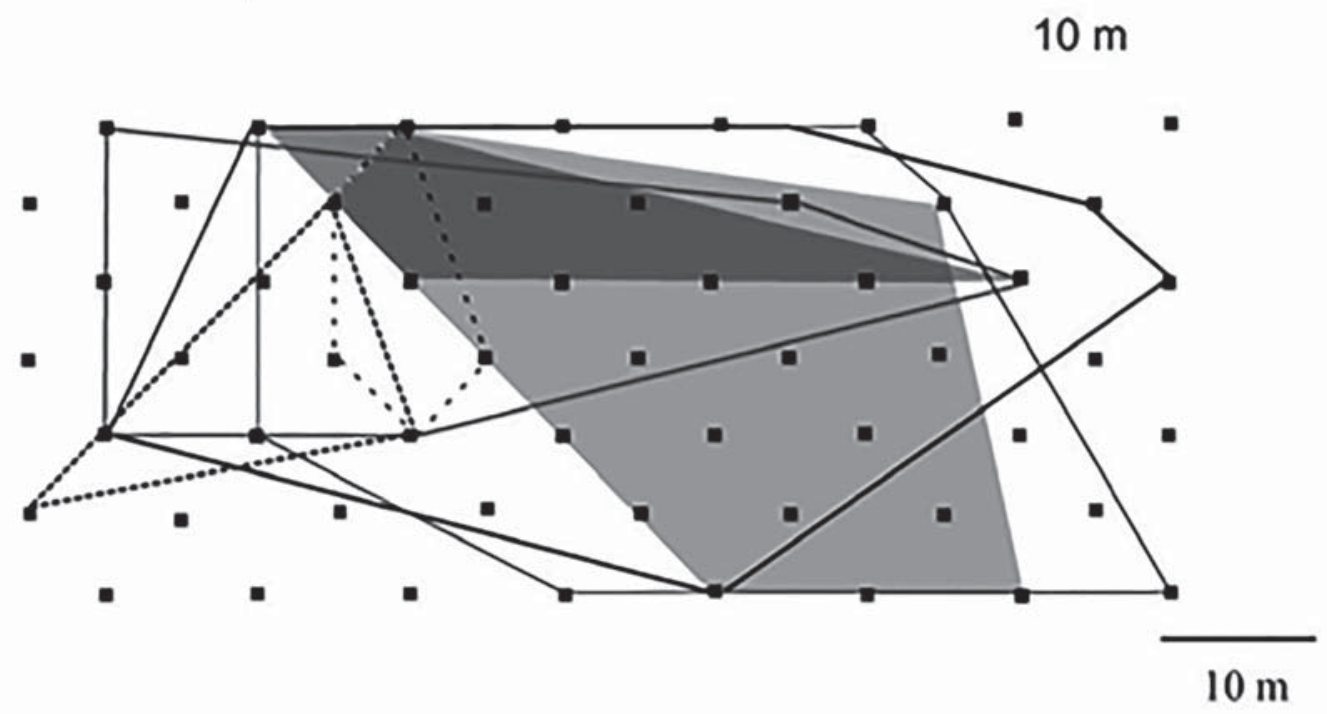

Fig. 3. Spatial organization of resident Mongolian voles as revealed by live-trapping: A) lengths of home ranges in 2011; B) home ranges plotted as Minimum Convex Polygons in 2013. Overwintered male home ranges are depicted in solid black lines without background, home ranges of males of the year - in solid black lines with oblique hatch; overwintered female home ranges are depicted in dashed lines without background, home ranges of females of the year - in shaded background without hatch. Identical letters indicate the members of the same supposed cluster of females.

Intrasexual and intersexual home range overlap. In high-density population (2011) the residents of each age-sex category displayed intrasexual and intersexual overlapping (Fig. 3A, Tab. 2). The pattern of female spatial distribution with overlapping of home ranges by as much as $90-100 \%$ for some dyads suggests the presence of clusters consisting of one-two overwintered and several females of the year (cluster A: two overwintered and at least two females of the year; cluster B: at least two overwintered and at least five females of the year; cluster C: two overwintered and at least one female of the year; cluster D: at least one overwintered and four females of the year, Fig. 3A). Not only had reproductive (pregnant and/or lactating) members of each cluster broadly overlapping home ranges, they also frequently visited the same traps during the same day, and were sometimes captured together. Voles within most of these clusters were apparently of the same ages, judging by their weights at the beginning of the study (cluster A: 10.5-11.5 g; cluster B: 14.5-16.5 g; cluster C: $16.5-17 \mathrm{~g}$, cluster D: 14.5$17.5 \mathrm{~g})$.

In 2011, one of four resident males occupied an exclusive home range, $77 \%$ of which overlapped with only one female group. Each of the remaining three males displayed extensive intrasexual overlapping and visited females from two or three different clusters (Fig. 3A). Of 12 females known to give birth during the study period five overlapped by two reproductive males and one female was overlapped by three males just before and/or after presumed postpartum estrous.

Despite the small number of trapped individuals, the general pattern of spacing appears to be the same in low-density population of 2013 (Fig. 3B). The home ranges of three resident males broadly overlapped. Although two resident overwintered females displayed 
Table 2. The number of individuals (median and limits in parentheses) overlapping resident Mongolian vole home ranges in 2011. OM - overwintered males; YM - males of the year; OF — overwintered females; $\mathrm{YF}$ - females of the year.

\begin{tabular}{|c|c|c|c|c|c|c|c|c|}
\hline \multirow{2}{*}{$\begin{array}{c}\text { Age-sex category of focal } \\
\text { overlapped animal }(n)\end{array}$} & \multicolumn{9}{|c|}{ Overlapper } \\
\cline { 2 - 9 } & OM & YM & OF & YF & OM & YM & OF & YF \\
\cline { 2 - 9 } & 2 & 4 & 5 & 9 & 1.5 & 3 & 1 & 1.5 \\
$(1-3)$ & $(1-7)$ & $(2-7)$ & $(2-11)$ & $(0-3)$ & $(2-4)$ & $(0-2)$ & $(1-4)$ \\
\hline OM (4) & 2 & 5 & 3 & 6 & 2 & 2 & 1 & 0 \\
& $(1-3)$ & $(0-5)$ & $(2-3)$ & $(1-8)$ & $(0-2)$ & $(1-4)$ & $(0-1)$ & $(0-2)$ \\
\hline YM (8) & 2 & 3 & 1.5 & 5 & 0.5 & 1.5 & 0.5 & 1 \\
& $(1-3)$ & $(1-6)$ & $(1-3)$ & $(1-9)$ & $(0-2)$ & $(0-4)$ & $(0-1)$ & $(0-3)$ \\
\hline OF (8) & 2 & 2 & 3 & 4 & 1 & 2 & 0 & 1 \\
& $(1-3)$ & $(1-7)$ & $(2-5)$ & $(1-6)$ & $(0-2)$ & $(1-4)$ & $(0-2)$ & $(0-3)$ \\
\hline
\end{tabular}

Table 3. Latency to approach a pup and duration of two parental behaviors (number of scans) exhibited by male and female Mongolian voles in tests. Medians with first and third quartiles in parentheses.

\begin{tabular}{|c|c|c|c|}
\hline Behavioral parameters & Males & Females & $\mathrm{Z}$-score, $p$ \\
\hline Latency & $143(10-240)$ & $111(33-240)$ & $\mathrm{Z}=0.6 ; p=0.55$ \\
\hline Tactile contact & $14(0-70)$ & $42(0-76)$ & $\mathrm{Z}=0.94 ; p=0.35$ \\
\hline Licking pup & $1(0-3)$ & $4(0-8)$ & $\mathrm{Z}=0.28 ; p=0.78$ \\
\hline
\end{tabular}

only marginal overlapping, one of them was repeatedly found in the traps visited during the same period by the third overwintered female categorized as non-resident. Two females of the year overlapped and were once captured together and with an overwintered resident female. It is worth noting that all five females captured in 2013 were pregnant or lactating. Each of two delivering females was overlapped by two males during the period around the birth.

\section{Parental behavior in laboratory}

Parental responsiveness in standard tests. Fathers did not significantly differ from mothers by any measure of parental responsiveness. Eleven of 15 females $(73 \%)$ and 10 of 15 males $(67 \%)$ made contact with pups. Among these voles, 11 females and nine males retrieved pups into shelter and did not transport them anymore. Nine females (60\%) and eight males (53\%) licked pups. Sex differences in time to approach pups, duration of tactile contact with pups, and duration of licking were nonsignificant (Tab. 3).

Parental behavior in semi-natural setting. The observed pairs differed dramatically by the pattern of nesting and the relative amounts of direct paternal care (Tab. 4). Two pairs exhibited permanent nest cohabitation. For these pairs, there were no differences between fathers and mothers in nest-residence time or time spent in tactile contact with pups, but mothers devoted signif- icantly more time to licking pups than did fathers. Sex difference in retrieving was statistically significant for one of these pairs (Tab. 4). The male of the third pair used both available shelters and spent significantly less time in the natal nest than did his female. He also spent less time in tactile contact with pups and devoted less time to licking in comparison with the female (Tab. 4). These three parental males spent in the natal nest 53.6$80.5 \%$ of time, spent in tactile contact with pups 51.8 $80.1 \%$ of time, and licked pups $1.3-8.3 \%$ of time. The fourth male spent most of the time in the shelter that did not contain the natal nest (Tab. 4). He was observed at the natal nest entry very infrequently. In only two cases out of 14 did the female aggression prevent him from getting into the nest. In other cases, the mother was absent (four instances) or did not display aggressive behavior (eight instances). This male approached pups and sniffed them only once, and was not engaged in any form of direct parental care.

\section{Discussion}

Spacing of free-living Mongolian voles

The first goal of this study was to characterize the space use by male and female Mongolian voles in the middle of the reproductive period. We conducted two trapping sessions, both at the same population, during the same period of summer, but under two contrast 
Table 4. Amounts of parental care (duration in sec per 40 min for nest residence, tactile contact and licking pups; total number of cases for retrieving pups) exhibited by male and female Mongolian voles in semi-natural conditions. Medians and first and third quartiles are presented.

\begin{tabular}{|c|c|c|c|c|c|}
\hline Pair number & Behavior & Nest residence & Tactile contact & Licking & Retrieving \\
\hline \multirow{3}{*}{ Pair 1} & male & $\begin{array}{c}2400 \\
(1520-2400) \\
\end{array}$ & $\begin{array}{c}2227 \\
(1619-2400) \\
\end{array}$ & $\begin{array}{c}175 \\
(86-290) \\
\end{array}$ & 22 \\
\hline & female & $\begin{array}{c}2311 \\
(1471-2400) \\
\end{array}$ & $\begin{array}{c}1903 \\
(1295-2361)\end{array}$ & $\begin{array}{c}244 \\
(135-411)\end{array}$ & 85 \\
\hline & Z-score, $p$ & $\begin{aligned} \mathrm{Z} & =0.01 \\
p & =0.99\end{aligned}$ & $\begin{array}{l}\mathrm{Z}=1.07 \\
p=0.280\end{array}$ & $\begin{array}{l}\mathrm{Z}=2.21 \\
p=0.027\end{array}$ & $\begin{array}{l}\chi^{2}=35.9 \\
p<0.001\end{array}$ \\
\hline \multirow{3}{*}{ Pair 2} & male & $\begin{array}{c}1685 \\
(1148-2369) \\
\end{array}$ & $\begin{array}{c}1651 \\
(1058-2350) \\
\end{array}$ & $\begin{array}{c}167 \\
(62-251) \\
\end{array}$ & 16 \\
\hline & female & $\begin{array}{c}1528 \\
(1061-2045) \\
\end{array}$ & $\begin{array}{c}1512 \\
(1041-1991) \\
\end{array}$ & $\begin{array}{c}350 \\
(242-418) \\
\end{array}$ & 29 \\
\hline & Z-score, $p$ & $\begin{aligned} \mathrm{Z} & =0.73 \\
p & =0.47\end{aligned}$ & $\begin{array}{c}\mathrm{Z}=0.53 \\
p=0.6\end{array}$ & $\begin{array}{l}\mathrm{Z}=3.49 \\
p<0.001\end{array}$ & $\begin{array}{c}\chi^{2}=3.2 \\
p=0.074\end{array}$ \\
\hline \multirow{3}{*}{ Pair 3} & male & $\begin{array}{c}2118 \\
(37-2400)\end{array}$ & $\begin{array}{c}2081 \\
(16-2400)\end{array}$ & $\begin{array}{c}12 \\
(0-38)\end{array}$ & 0 \\
\hline & female & $\begin{array}{c}2259 \\
(1355-2400) \\
\end{array}$ & $\begin{array}{c}2251 \\
(1257-2400) \\
\end{array}$ & $\begin{array}{c}150 \\
(76-255) \\
\end{array}$ & 2 \\
\hline & Z-score, $p$ & $\begin{array}{l}\mathrm{Z}=2.31 \\
p=0.021\end{array}$ & $\begin{array}{l}\mathrm{Z}=2.28 \\
p=0.023\end{array}$ & $\begin{array}{l}\mathrm{Z}=4.35 \\
p<0.001\end{array}$ & ns \\
\hline \multirow{3}{*}{ Pair 4} & male & $\begin{array}{c}0 \\
(0-3)\end{array}$ & 0 & 0 & 0 \\
\hline & female & $\begin{array}{c}2260 \\
(1906-2400) \\
\end{array}$ & $\begin{array}{c}2142 \\
(1696-2400) \\
\end{array}$ & $\begin{array}{c}241 \\
(0-419) \\
\end{array}$ & 27 \\
\hline & Z-score, $p$ & $\begin{array}{l}\mathrm{Z}=4.94 \\
p<0.001\end{array}$ & $\begin{array}{l}\mathrm{Z}=4.94 \\
p<0.001\end{array}$ & $\begin{array}{c}\mathrm{Z}=4.7 \\
p<0.001\end{array}$ & $\begin{array}{c}\chi^{2}=3.2 \\
p<0.001\end{array}$ \\
\hline
\end{tabular}

density conditions and at different habitat configurations. Only the data obtained in 2011 were possible to analyze statistically. Reproductive males had larger daily movement distances, and occupied larger home ranges in comparison with females and non-reproductive males. The larger proportion of resident individuals among females than among males suggests that females exhibit stronger site tenacity. Thus, males appear to seek multiple females for mates. The patterns of overlapping observed in 2011 and 2013 were similar. Female home ranges were extensively overlapped by several males, and each adult resident male visited home ranges of several reproductive females. Male home ranges also broadly overlapped. This set of home range characteristics is considered to be indicative of promiscuous mating system (Tab. 1).

The lack of male territoriality in the high density population trapped in 2011 is rather unexpected, given the distribution of reproductive females and taking into account habitat linearity. In most studied arvicolines, promiscuity and male non-defense reproductive strategy are associated with and considered to be resulted from female territoriality (Microtus breweri (Baird, 1857) - Zwicker, 1990; M. canicaudus Miller, 1897 Wolff et al., 1994; M. oeconomus (Pallas, 1976) Gliwicz, 1997; M. pennsylvanicus (Ord, 1815) - Madison, 1980). However, the spatial relationships among female Mongolian voles in 2011 suggest the presence of clusters consisting of several reproductive individuals. The overlapping young females may be littermates which became established as breeders within older female's (mother's?) home range. The formation of female kin aggregations at high densities, usually at the end of reproductive period, is typical for many Microtus species (Microtus agrestis (Linnaeus, 1761) Myllymaki, 1977; Agrell, 1994; M. arvalis - Boyce \& Boyce, 1988a, b; M. californicus (Peale, 1848) Ostfeld, 1986; Heske, 1987; M. oeconomus — Tast, 1966; Lambin et al., 1992). In some species, female philopatry does not modify the distribution of female breeders as daughters do not mature while living with dams (Microtus montanus (Peale, 1848) - Jannett, 1978; M. pennsylvanicus - Madison, 1980; Ostfeld et al., 1988). In those species that do not display reproductive suppression of philopatric females, males seem to exhibit the predicted response to clumped female distribution: they became territorial (Microtus agrestis Myllymaki, 1977; Agrell, 1994; M. californicus Ostfeld, 1986; M. oeconomus — Tast, 1966; Lambin et al., 1992; Gliwicz, 1997). Female aggregations visited by multiple overlapping males has been reported for Neotoma cinerea (Ord, 1815) (Topping \& Millar, 1996) and may be characteristic of M. arvalis (Boyce \& Boyce, 1988a, b; Borkowska \& Ratkiewicz, 2010; Smorkatche- 
va, unpublished data), but generally this pattern of spacing appears to be rather uncommon for rodents, including arvicolines.

Other things being equal, the defensibility of a home range should be higher in a linear than in a non-linear habitat, because of lower number of neighbors and shorter border lines between neighboring territories (Fauske et al., 1997). In accordance with this proposition, male root voles living within a narrow fenced area displayed totally exclusive home ranges (Fauske et al., 1997). In our study, the strip inhabited by Mongolian voles $(5-15 \mathrm{~m})$ was not fenced and was an order of magnitude wider than a linear habitat in the study of Fauske and co-workers $(1.5 \mathrm{~m})$. Probably, the decreasing of border lines in our population was not sufficient to make territory defense more feasible.

Rodent spacing and mating strategies are thought to be connected with abundance, renewability and distribution of food, and hence its defensibility by, and spacing of, females (Ostfeld, 1985, 1990). Briefly, Ostfeld's model predicts that in species feeding on fastgrowing, abundant, and evenly distributed herbs, females would not need to exhibit territoriality. The diet of M. mongolicus is little known, though our preliminary observations suggest that the Mongolian voles feed mainly on monocots (Bazhenov, 2011). If it is true, then the overlapping between some overwintered females as well as between reproductive females of the year fits the Ostfeld's predictions.

Paternal behavior under laboratory conditions

Rearing pups in covered nests or subterranean burrows precludes observation and measurement of arvicoline parental behavior in nature. Several laboratory methods are used for revealing species, sexual or other differences in the level of parental care. Often there are some discrepancies in the results obtained by different ways, and the interpretation of the findings should depend on the experimental conditions (Dewsbury, 1985; McGuire \& Bemis, 2007). Thus, the data obtained with parent-litter separation paradigm and the results of undisturbed observation of animals in large enclosures will be discussed separately.

Most male Mongolian voles living in small cages with dams and pups of the first litters displayed pronounced paternal behavior in standard tests. Moreover, we did not found significant sex difference in any measure of parental responsiveness. A number of arvicoline rodents exhibits paternal behavior under similar housing conditions. The list includes several monogamous species (Microtus guentheri (Danford \& Alston, 1880) Libhaber \& Eilam, 2004; M. ochrogaster - Hartung \& Dewsbury, 1979; Solomon, 1993; M. socialis (Pallas, 1773) - Gromov, 2010), those living in communal/ cooperative family groups (Lasiopodomys brandti (Radde, 1861) - Gromov, 2010; Lasiopodomys mandarinus (Milne-Edwards, 1871) — Smorkatcheva, 2003), and a few promiscuous species that do not form pair bonds (M. montanus - Hartung \& Dewsbury, 1979; M. pennsylvanicus - Hartung \& Dewsbury, 1979;
Storey \& Snow, 1987, Parker \& Lee, 2001; Dicrostonyx richardsoni Merriam, 1900 - Shilton \& Brooks, 1989). In common with M. mongolicus, most of these species showed no sex difference in nest-attendance or contact with pups, but fathers were usually reported to spend less time than females licking pups. However, this difference decreased, disappeared or even inverted when the authors estimated the same behavior in the absence of another parent using separation paradigm (M. arvalis, $M$. socialis, L. brandti, L. mandarinus Smorkatcheva et al., 2011; M. ochrogaster — Lonstein \& De Vries, 1999; M. pennsylvanicus - Hartung \& Dewsbury, 1979). Proximately, sensory cues from pups and dam may induce parental responsiveness in both monogamous males and males of those species that do not display paternal behavior in their natural environment (e.g., Elwood, 1985; Storey \& Joyce, 1995; Terleph et al., 2004). It should be though noted that the pattern where fathers living with dams and pups in small cages exhibit the level of parental responsiveness/direct care similar to that of mother does not hold true for all voles. For example, in promiscuous Myodes rutilus (Pallas, 1779) (Gromov, 2009) and Myodes glareolus (Schreber, 1780) (Gromov \& Osadchuk, 2013), the pronounced sex differences in parental responsiveness along with high individual variability of pup-oriented behavior has been revealed even in small cages. Strong sex differences in at least one measure of direct parental care, licking pups, were found for steppe lemmings (Eolagurus luteus (Eversmann, 1840) Smorkatcheva et al., 2011; Lagurus lagurus (Pallas, 1773) - Gromov, 2010; Smorkatcheva et al., 2011), using both undisturbed observations in small home cages and parent-litter separation paradigm. Although the characteristics of mating system of steppe lemmings are poor known, there are some evidences of pairbonding and living in family groups (Malkova et al., 2004; Evsikov et al., 2006; Smorkatcheva et al., 2009). Given together, these data hint that phylogeny rather than mating system may affect the sex differences in parental responsiveness (Smorkatcheva et al., 2011), and that promiscuous voles of genus Microtus readily exhibit paternal care, at least after the short period of exposure to pups. The results of our study of M. mongolicus are consistent with this idea.

Our observations of breeding pairs housed under standard conditions in large enclosures revealed strong individual variation in the pattern of male-female as well as father-young interactions. Our sample size was too small to attempt to correlate these differences with any specific factor (current or previous litter size, age of parents, body mass, etc.). McGuire (1997: 839-849) reported the similar variation in nest-attendance by male red-backed voles, Myodes gapperi (Vigors, 1830), and proposed the female behavior to determine whether males spent time in nest and contacted with young. The same may be true for $M$. mongolicus although according to our observations, the "non-paternal" male did not exhibit much interest to the pups independently on the female presence and reaction. In the McGuire's study, 
Myodes gapperi males did not display direct parental care during their nest attendance. In contrast, those male Mongolian voles which shared the nests with dams and pups were intimately involved in raising the offspring. Judging by the amount of time devoted to tactile contact and licking pups, their contributions to the parental care during the first week postpartum were higher than the average male's contributions in two monogamous voles (contact: M. ochrogaster - 30-35\%, M. pinetorum - 10-20\%; grooming: M. ochrogaster $1-4 \%, M$. pinetorum - less than $2 \%$; values for $M$. ochrogaster and $M$. pinetorum are calculated from the data presented in Fig. 1 in Oliveras \& Nowak, 1986).

M. mongolicus is not the only promiscuous vole which displays pronounced paternal care under seminatural conditions. Besides Myodes gapperi, three apparently promiscuous species have been examined for nesting pattern and parental behavior with similar methods. Among them, only the M. montanus males invariably displayed separate nesting and no parental behavior (McGuire \& Nowak, 1986), while male collared lemmings, Dicrostonyx richardsoni, provided a great deal of parental care (Gajda \& Brooks, 1993). Microtus pennsylvanicus' behavior dramatically varied depending on the population (McGuire \& Nowak, 1984; Oliveras \& Nowak, 1986; Storey \& Snow, 1987). While the care-giving behavior exhibited by male rodents housed in small cages may be artifacts of forced coexistence with dams and pups, the same behavior observed in semi-natural settings is thought to reflect the male's reproductive option occurring in field under particular circumstances. In both collared lemming and meadow vole, pair nesting and biparental care are supposed to be associated with winter breeding. In cold environment, male-female cohabitation and paternal care should be advantageous in terms of energy conservation: mates might reduce their thermoregulatory costs by staying together in the nest, and the male could keep the pups warm whenever the female left the nest to feed (Storey \& Snow, 1987; Gajda \& Brooks, 1992). To date, there is no evidence of winter reproduction for M. mongolicus, and our preliminary data suggest it to be unlikely (Bazhenov, 2011). Alternatively, the enormous density fluctuations creating dramatic variations in social environment might result in the selection for behavioral flexibility or coexistence of several behavioral phenotypes. Under extremely low or high densities, male deserting is unlikely to be rewarded by the encounter of getting access to a new receptive female, and higher paternal motivation might be favored. In our laboratory experiments, the isolation of the focal breeding pairs from other conspecifics might imitate the low-density conditions and thus predispose males to care-giving behavior.

The present work is the first one to examine the spatial structure and parental strategy of the Mongolian vole. Though limited in the sample sizes and duration of the trapping period, our field study provides good indication of the promiscuous mating system. It is important that the spacing pattern consistent with this type of sexual relationships, in particular the tendency for individual home ranges to overlap with multiple potential reproductive partners, was observed under different habitat configuration and population density. Obviously, our proposition should be verified using genetic analyses of paternity and reproductive success. Anyway, we are confident that M. mongolicus is not a monogamous species. The pattern of copulatory behavior, specifically, high ejaculation frequency reported for the Mongolian vole by Zorenko (2013: 541) provides some additional support for this conclusion.

Due to the limitations of the capture-mark-recapture method we could not examine the nesting pattern of free-living Mongolian voles. Based on our laboratory data, sharing nests by males and reproductive females appears to be quite possible for this species. Although paternal care may not represent the predominant strategy in free-living males, our observations demonstrate a capacity of males to exhibit a very high parental responsiveness comparable to that of socially monogamous species. Taken together, our results show that male parental responsiveness and care-giving behavior do not consistently vary with mating system across vole species, and that monogamous mating system cannot be inferred from observations of biparental care in captivity.

ACKNOWLEDGEMENTS. We are grateful to the staff of the State Nature Biosphere Reserve «Daursky», and particularly A.P. Borodin, for the support in organization of field studies. We thank Yu.M. Koval'skaya and Yu.G. Bojarinova for their field assistance, and A.D. Mironov for his help in construction of pens. We are also thankful to F.N.Golenishchev for reviewing the manuscript of this paper and useful comments. This study was supported by Russian Foundation for Basic Research (12-04-01338-a and 16-04-00479-a) and the Saint-Petersburg State University research grant (1.0.124.2010). All procedures performed in this study were in accordance with the ethical standards of the Saint Petersburg State University.

\section{References}

Abramsky Z. \& Tracy C.R. 1980. Relation between home range size and regulation of population size in Microtus ochrogaster // Oikos. Vol.34. P.347-355.

Abramson N.I., Lebedev V.S., Tesakov A.S. \& Bannikova A.A. 2009. [Supraspecies relationships in the subfamily Arvicolinae (Rodentia, Cricetidae): an unexpected result of nuclear gene analysis] // Molekulyarnaya Biologiya. Vol.43. P.834-846 [in Russian, with English abstract].

Agrell J. 1994. A shift in female social organization independent of relatedness: an experimental study on the field vole (Microtus agrestis) // Behavioral Ecology. Vol.6. P.182-191

Altmann J. 1974. Observational study of behaviour: sampling methods // Behavioral. Vol.49. P.227-267

Bannikova A.A., Lebedev V.S., Lissovsky A.A., Matrosova V., Abramson N.I., Obolenskaya E.V. \& Tesakov A.S. 2010. Molecular phylogeny and evolution of the Asian lineage of vole genus Microtus (Rodentia: Arvicolinae) 
inferred from mitochondrial cytochrome $b$ sequence // Biological Journal of the Linnean Society. Vol.99. P.595613.

Bazhenov Y.A. 2011. [New data on the ecology of the Mongolian vole (Microtus mongolicus) in Transbaikalia region] // Proceedings of the International Meeting "Theriofauna of Russia and Adjacent Territories" (9 Congress of the Theriological Society of RAS), Moscow. P.36 [in Russian].

Borkowska A. \& Ratkiewicz M. 2010. Promiscuity, male reproductive success and mate relatedness in a natural population of the common vole // Journal of Zoology. Vol.280. P.195-201.

Boyce C.C.K. \& Boyce J.L. 1988a. Population biology of Microtus arvalis. II Natal and breeding dispersal of females // Journal of Animal Ecology. Vol.57. P.723-736.

Boyce C.C.K. \& Boyce J.L. 1988b. Population biology of Microtus arvalis. III. Regulation of numbers and breeding dispersion of females // Journal of Animal Ecology. Vol.57. P.737-754.

Buchan J.C., Alberts S.C., Silk J.B. \& Altmann J. 2003. True paternal care in a multi-male primate society // Nature. Vol.425. P.179-181.

Conroy C.J. \& Cook J.A. 2000. Molecular systematics of a Holarctic rodent (Microtus: Muridae) // Journal of Mammalogy. Vol.81. P.344-359.

Dewsbury. 1985. Paternal behavior in rodents // American Zoologist. Vol.25. P.841-52.

Elwood R.V. 1985. Inhibition of infanticide and onset of paternal care in male mice (Mus musculus) // Journal of Comparative Psychology. Vol.99. P.457-467.

Evsikov V.I., Kokenova G.T., Zadubrovskii P.A., Potapova O.F. \& Potapov M.A. 2006. Monogamy as one of the ways of realization of the adaptive potential in mammals as exemplified by the steppe lemming Lagurus lagurus Pallas // Doklady Biological Sciences. T.411. P.501503.

Fauske J., Andreassen H.P. \& Ims R.A. 1997. Spatial organization in a small population of the root vole Microtus oeconomus in a linear habitat// Acta Theriologica. Vol.42. P.79-90.

Fietz J. \& Dausmann K.H. 2003. Cost and potential benefits of parental care in the nocturnal fat-tailed dwarf lemur (Cheirogaleus medius) // Folia Primatologica. Vol.74. No.5-6. P.246-268.

FitzGerald R.W. \& Madison D.M. 1983. Social organization of a free-ranging population of pine voles, Microtus pinetorum // Behavioral Ecology and Sociobiology. Vol.13. P.183-187.

Gaines M.S. \& Johnson M.L. 1982. Home range size and population dynamics in the prairie vole, Microtus ochrogaster // Oikos. Vol.39. P.63-70.

Gajda A.M. \& Brooks R.J. 1993. Paternal care in collared lemmings (Dicrostonyx richardsoni): artifact or adaptation? // Arctic. Vol.46. P.312-315.

Galewski T., Tilak M., Sanchez S., Chevret P., Paradis E. \& Douzery E. 2006. The evolutionary radiation of Arvicolinae rodents (voles and lemmings): relative contribution of nuclear and mitochondrial DNA phylogenies // BMC Evolutionary Biology. 6: 80.

Gaulin S.J.C \& FitzGerald R.W. 1988. Home range size as a predictor of mating systems in Microtus // Journal of Mammalogy. Vol.69. P.311-319.

Gliwicz J. 1997. Space use in the root vole: basic patterns and variability // Ecography. Vol.20. P.383-389.
Gromov V.S. 2009. Parental care in captive red-backed vole (Clethrionomys rutilus) // Contemporary Problems of Ecology. Vol.16. No.3. P.467-473.

Gromov V.S. 2010. Interactions in family pairs and parental care in captive steppe lemming (Lagurus lagurus) // Contemporary Problems of Ecology. Vol. 3. P.133-139.

Gromov V.S. 2011. Pair-bonding and parental care in cricetid rodents: a comparative study // Acta Theriologica. Vol.56. P.23-33.

Gromov V.S. 2013. [Parental care, in rodents: physiological, behavioral and evolutionary aspects]. Moscow: KMK Scientific Press. 584 p. [in Russian].

Gromov V.S. \& Osadchuk L.V. 2013. Parental care and testosterone in males of the bank vole (Myodes glareolus): sensitization and androgenic stimulation of paternal behavior // Biological Bulletin. T.40. No.1. P.114-118.

Hartung T.G. \& Dewsbury D.A. 1979. Paternal care in six species of muroid rodents // Behavioral and Neural Biology. Vol.26. P.466-478.

Hasler J.F. 1975. A review of reproduction and sexual maturation in the microtine rodents // The Biologist. Vol.57. P.52-86.

Heske E.J. 1987. Spatial structuring and dispersal in a high density population of the California vole Microtus californicus // Holarctic Ecology. Vol.10. No.2. P.137-148.

Ims R.A. 1987. Responses in spatial-organization and behavior to manipulations of the food resource in the vole Clethrionomys rufocanus // Journal of Animal Ecology. Vol.56. P.585-96.

Jaarola M., Martínková N., Gündüz I., Brunhoff C., Zima J., Nadachowski A., Amori G., Bulatova N.S., Chondropoulos B., Fraguedakis-Tsolis S., González-Esteban J., López-Fuster M.J., Kandaurov A.S., Kefelioglu H., Mathias M.D., Villate I. \& Searle J.B. 2004. Molecular phylogeny of the speciose vole genus Microtus (Arvicolinae, Rodentia) inferred from mitochondrial DNA sequences // Molecular Phylogenetics and Evolution. Vol.33. P.647663.

Jannett F.J., Jr. 1978. The density-dependent formation of extended maternal families of the montane vole, Microtus montanus nanus // Behavioral Ecology and Sociobiology. Vol.3. P.245-263.

de Jong T.R., Chauke M., Harris B.N. \& Saltzman W. 2009. From here to paternity: neural correlates of the onset of paternal behavior in California mice (Peromyscus californicus) // Hormones and Behavioral. Vol.56. P.220-231.

Komers P.E. \& Brotherton P.N.M. 1997. Female space use is the best predictor of monogamy in mammals // Proceedings: Biological Sciences. Vol.264. P.1261-1270.

Lambin X., Krebs C. \& Scott B. 1992. Spacing system of tundra vole (Microtus oeconomus) during the breeding season in Canada's western Arctic // Canadian Journal of Zoology. Vol.70. P.2068-2072.

Libhaber N. \& Eilam D. 2004. Parental investment in social voles varies and is relatively independent of litter size // Journal of Mammalogy. Vol.85. P.748-755.

Lonstein J.S. \& De Vries G.J. 1999. Sex differences in the parental behaviour of adult virgin prairie voles: Independence from gonadal hormones and vasopressin // Journal of Neuroendocrinology. Vol.11. P.441-449.

Madison D.M. 1980. Space use and social structure in meadow vole, Microtus pennsylvanicus // Behavioral Ecology and Sociobiology. Vol.7. P.65-71.

Malkova M.G., Palchekh N.A., Yakimenko V.V. \& Kuzmin I.V. 2004. [The spatiotemporal structure of rodent popu- 
lations in the steppe zone of Western Siberia]// Ekologiya. Vol.1. P.34-42 [in Russian, with English abstract].

McGuire B. 1997. Influence of father and pregnancy on maternal care in red-backed voles // Journal of Mammalogy. Vol.78. No.3. P.839-849.

McGuire B. \& Bemis W. 2007. Litter size influences maternal but not paternal care in three species of voles, as measured by nest attendance // Journal of Mammalogy. Vol.88. No.6. P.1420-1426.

McGuire B. \& Getz L.L. 1998. The nature and frequency of social interactions among free-living prairie voles $(\mathrm{Mi}$ crotus ochrogaster) // Behavioral Ecology and Sociobiology. Vol.43. P.271-279.

McGuire B. \& Novak M. 1984. A comparison of maternal behaviour in the meadow vole (Microtus pennsylvanicus), prairie vole (M. ochrogaster) and pine vole $(M$. pinetorum) // Animal Behaviour. Vol.32. P.1132-1141.

McGuire B. \& Novak M. 1986. Parental care and its relationship to social organization in the montane vole (Microtus montanus) // Journal of Mammalogy. Vol.67. P.305-11.

Meyer M.N., Golenishchev F.N., Radjabli S.I. \& Sablina O. V. 1996. [Voles (subgenus Microtus Schrank) of Russia and adjacent territories] // Proceedings of the Zoological Institute RAS. Vol.232. P.1-320 [in Russian].

Miller D.H. \& Getz L.L. 1969. Life-history notes on Microtus pinetorum in Central Connecticut // Journal of Mammalogy. Vol.50. P.777-784.

Myllymaki A. 1977. Intraspecific competition and home range dynamics in the field vole Microtus agrestis // Oikos. Vol.29. P.553-569.

Nekipelov N.V. 1935. [Data on the ecology of the rodents from vicinity of Barun-Torey Lake] // Izvestiya Irkutskogo Nauchnogo Issledovatel'skogo Protivochumnogo Instituta Sibiri i Dal'nego Vostoka. T.2. P.64-103 [in Russian].

Oliveras D. \& Novak M. 1986. A comparison of paternal behaviour in the meadow vole Microtus pennsylvanicus, the pine vole $M$. pinetorum and the prairie vole $M$. ochrogaster // Animal Behavior. Vol.34. P.519-526.

Ostfeld R.S. 1985. Limiting resources and territoriality in microtine rodents // The American Naturalist. Vol. 126. P.1-15.

Ostfeld R.S. 1986. Territoriality and mating system of California voles // Journal of Animal Ecology. Vol.55. P.691706.

Ostfeld R.S. 1990. The ecology of territoriality in small mammals // Trends in Ecology and Evolution Vol.5. P.411-415.

Ostfeld R.S., Pugh S.R., Seamon J.O. \& Tamarin R.H. 1988. Space use and reproductive success in a population of meadow voles // Journal of Animal Ecology. Vol.57. P.385-394.

Parker K.J. \& Lee T.M. 2001. Social and environmental factors influence the suppression of pub-directed aggression and development of paternal behavior in captive meadow voles (Microtus pennsylvanicus) // Journal of Comparative Psychology. Vol.115. P.331-336.

Pusenius J. \& Viitala J. 1995. Familiarity of breeding field vole (Microtus agrestis) females does not affect their space use and demography of the population // Annales Zoologici Fennici. Vol.32. P.217-223.

Schradin C. \& Pillay N. 2003. Paternal care in the social and diurnal striped mouse (Rhabdomys pumilio): laboratory and field evidence // Journal of Comparative Psychology. Vol.117. P.317-324.
Schradin C. \& Pillay N. 2005. Intraspecific variation in the spatial and social organization of the African striped mouse // Journal of Mammalogy. Vol.86. P.99107.

Shilton C.M. \& Brooks R.J. 1989. Paternal care in captive collared lemmings (Dicrostonyx richardsoni) and its effect on development of the offspring // Canadian Journal of Zoology. Vol.67. P.2740-2745.

Smorkatcheva A.V. 2003. Parental care in the captive mandarin vole, Lasiopodomys mandarinus // Canadian Journal of Zoology. Vol.81. P.1339-1345.

Smorkatcheva A.V. \& Bulatova E.V. 2009. [Social structure and spacing in the yellow steppe lemming, Eolagurus luteus, under semi-natural conditions] // Proceedings of the Scientific Conference on Mammalian Behavior and Behavioral Ecology, Moscow. P.42 [in Russian].

Smorkatcheva A.V., Bychenkova T.N. \& Zavjalov E.L. 2010. Parental responsiveness negatively correlates with fecal testosterone concentration in male mandarin voles $(\mathrm{Mi}$ crotus mandarinus) // Journal of Ethology. Vol.28. P.5360.

Smorkatcheva A.V., Bychenkova T.N. \& Kowalskaya Y.M. 2011. [Parental responsiveness in voles: the effect of mating system and phylogeny] // Proceedings of the International Meeting "Theriofauna of Russia and Adjacent Territories" (9 Congress of the Theriological Society of RAS), Moscow. P.449 [in Russian].

Solomon N.G. 1993. Comparison of parental behaviour in male and female prairie voles (Microtus ochrogaster) // Canadian Journal of Zoology. Vol.71. P.434-37.

Storey A.E. \& Joyce T.L. 1995. Pup contact promotes paternal responsiveness in male meadow voles // Animal Behavior. Vol.49. P.1-10.

Storey A.E. \& Snow D.T. 1987. Male identity and enclosure size affect paternal attendance of meadow voles, Microtus pennsylvanicus // Animal Behavior. Vol.35. P.411419.

Tast J. 1966. The root vole, Microtus oeconomus (Pallas), as an inhabitant of seasonally flooded land // Annales Zoologici Fennici. Vol.3. P.127-171.

Terleph T.A., Jean-Baptiste N. \& Bamshad M. 2004. Mechanisms and time course for induction of paternal behavior in prairie voles (Microtus ochrogaster) // Journal of Mammalogy. Vol.85. P.1124-1129.

Topping M.G. \& Millar J.S. 1996. Spatial distribution in the bushy-tailed woodrat (Neotoma cinerea) and its implications for the mating system // Canadian Journal of Zoology. Vol.74. P.565-569.

Wolff J.O., Edge W.D. \& Bentley R. 1994. Reproductive and behavioral biology of the gray-tailed vole // Journal of Mammalogy. Vol.75. P.873-879.

Xia X. \& Millar J.S. 1988. Paternal behavior by Peromyscus leucopus in enclosures // Canadian Journal of Zoology. Vol.66. P.1184-87.

Zorenko T.A. 1986. [Copulation patterns and their importance for rodent taxonomy and comparative ecology] // Proceedings of the 4-th Congress of the Theriological Society, Moscow. Vol.1. P.62-63 [in Russian].

Zorenko T. 2013. [Social Voles of the Subgenus Sumeriomys: Taxonomy, Biology and Behavior]. Saarbrücken: Palmarium Academic Publishing. 541 p. [in Russian].

Zwicker K. 1990. Social structure of the beach vole, Microtus breweri // Tamarin R.H., Ostfeld R.S., Pugh S.R. \& Bujalska G. (eds). Social Systems and Population Cycles in Voles. Basel \& Boston: Illus Birkhaeuser Verlag. P.143-153. 